\title{
Effect of Three Planting Dates on Three Types of Garlic in Southwest Missouri
}

\author{
Clydette Alsup-Egbers ${ }^{1}$, Patrick Byers ${ }^{2}$, Kelly McGowan ${ }^{2}$, \\ Pamela B. Trewatha ${ }^{1}$, and William E. McClain ${ }^{1}$
}

\begin{abstract}
AdDitional INDEX wORDs. Allium ampeloprasum, Allium sativum, precipitation, temperature, yield

SumMary. Commercial garlic (Allium sativum) is a relatively new crop for Missouri growers. While U.S. production is primarily in California, Oregon, Washington, and New York, little information is available regarding growing garlic in Missouri's climate and soil conditions. Therefore, research is needed to investigate the optimum planting date for garlic in southwest Missouri. Comparisons between one spring and four fall planting dates using two garlic cultivars (Inchelium Red and German White) and the leek (Allium ampeloprasum) known as elephant garlic $(A$. ampeloprasum ssp. ampeloprasum) were planted at two replicated sites. Postharvest data were collected on bulb weight and diameter and clove weight and quantity. Although the numbers were not always statistically different, the overall results indicated that earlier planted garlic (September and early-October) had higher yields in 2016-17 than garlic planted later; however, in 2017-18, garlic planted in mid-October and early-November out-yielded garlic planted in September and early-October. Fall planting is preferred based on the results of our study, but spring-planted garlic can still yield a profitable crop for commercial growers. Future research on a variety of planting dates will give producers a better choice on when to plant in southwest Missouri.
\end{abstract}

$\mathrm{G}$ arlic (Allium sativum) is one of the 20 most important vegetables in the world, with an annual production of $\approx 25$ million tonnes (World Atlas, 2017). Garlic is thought to have originated in an area from China to India to Egypt to the Ukraine (U.S. Department of Agriculture, 2019). China dominates the world garlic industry (Lipka, 2011), producing more than $80 \%$ of the world tonnage (World Atlas, 2017). Although the United States is the world's largest importer of fresh garlic (Boriss, 2006), it is also a valuable crop for U.S. growers. Garlic sells for as much as $\$ 2$ to $\$ 4$ per pound in the United States, with a potential value between $\$ 1400$ to $\$ 3200$ per acre (Bachman and Hinman, 2008). Total value of U.S. commercial garlic

Received for publication 11 July 2019. Accepted for publication 18 Feb. 2020.

Published online 19 March 2020.

${ }^{1}$ Department of Environmental Plant Science and Natural Resources, Missouri State University, Springfield, MO 65897

${ }^{2}$ University of Missouri Extension, Columbia, MO 65211

C.A.-E. is the corresponding author. E-mail: clydettealsup@ missouristate.edu.

This is an open access article distributed under the CC BY-NC-ND license (https://creativecommons.org/ licenses/by-nc-nd/4.0/).

https://doi.org/10.21273/HORTTECH04457-19 production was \$138.5 million in 2014 (Boriss, 2006). California produces $\approx 85 \%$ of the garlic grown in the United States (Walters, 2008); Nevada, Oregon, and Washington also grow significant acreage (Boriss, 2006; Ford et al., 2014; Walters, 2008), with New York ranked fifth in U.S. production with more than 300 acres (Cornell Cooperative Extension, 2019). Garlic has a higher nutritional value than other bulb crops (Naruka and Dhaka, 2001) and Americans consume an average of $2 \mathrm{lb}$ of garlic per person each year, an amount that has steadily increased since the $1920 \mathrm{~s}$ (Boriss, 2006).

Garlic is a perennial that belongs in the Amaryllidaceae family. All parts of garlic are edible except for the roots and the paper-like covering that encloses each clove (Encyclopedia Britannica, 2016). All garlic used for culinary purposes is from the species A. sativum, which has two subspecies, A. sativum ssp. ophioscorodon, known as hardneck (or bolting) garlic, and $A$. sativum ssp. sativum, known as softneck (or nonbolting) garlic (U.S. Department of Agriculture, 2019). Hardneck garlic is easily identified when it produces a long flower stalk, commonly referred to as a scape. The scapes are edible when cut from the plant while tender and no longer than 16 inches or more than one-quarter of an inch in diameter (Bachman and Hinman, 2008). In fact, scape removal improved bulb yield from $5 \%$ to $15 \%$ in a Minnesota study, depending on the amount of organic matter in the soil (Rosen and Tong, 2001). Hardneck garlic is more flavorful and the skin can be peeled from the cloves more easily (Frederick et al., 2014); therefore, it is favored by gourmet chefs. The mild hardneck scapes are also edible (Frederick et al., 2014). Softneck garlic is easier to grow and is the type of garlic usually found in grocery stores. Softneck garlic typically has a shelf life 6 to 8 months compared with a 2- to 4-month shelf life for hardneck garlic (Frederick et al., 2014). Hardneck cultivars have a single layer of six to eight cloves arranged around the flower stalk (Walters, 2008). Softneck cultivars have cloves arranged in three to six layers around each other, totaling $\approx 12$ to 25 cloves per bulb. They are sometimes braided after harvest because they do not have the flower scape growing up the center (Walters, 2008). The outer layer tends to have larger cloves, whereas the inside layers of cloves become progressively

\begin{tabular}{llll}
\hline $\begin{array}{l}\text { Units } \\
\text { To convert U.S. to SI, } \\
\text { multiply by }\end{array}$ & U.S. unit & SI unit & $\begin{array}{l}\text { To convert SI to U.S., } \\
\text { multiply by }\end{array}$ \\
\hline 0.4047 & acre $(\mathrm{s})$ & $\mathrm{ha}$ & 2.4711 \\
0.3048 & $\mathrm{ft}$ & $\mathrm{m}$ & 3.2808 \\
0.0929 & $\mathrm{ft}^{2}$ & $\mathrm{~m}^{2}$ & 10.7639 \\
2.54 & inch $(\mathrm{es})$ & $\mathrm{cm}$ & 0.3937 \\
25.4 & inch $(\mathrm{es})$ & $\mathrm{mm}$ & 0.0394 \\
0.4536 & $\mathrm{lb}$ & $\mathrm{kg}$ & 2.2046 \\
1.1209 & $\mathrm{lb} / \mathrm{acre}$ & $\mathrm{kg} \cdot \mathrm{ha}^{-1}$ & 0.8922 \\
1 & $\mathrm{meq} / 100 \mathrm{~g}$ & $\mathrm{cmol} \cdot \mathrm{kg}^{-1}$ & 1 \\
0.0254 & $\mathrm{mil}(\mathrm{s})$ & $\mathrm{mm}$ & 39.3701 \\
28.3495 & $\mathrm{oz}$ & $\mathrm{g}$ & 0.0353 \\
0.9072 & ton $(\mathrm{s})$ & tonne $(\mathrm{s})$ & 1.1023 \\
$\left({ }^{\circ} \mathrm{F}-32\right) \div 1.8$ & ${ }^{\circ} \mathrm{F}$ & ${ }^{\circ} \mathrm{C}$ & $\left({ }^{\circ} \mathrm{C} \times 1.8\right)+32$
\end{tabular}


smaller (Bachman and Hinman, 2008). Elephant garlic (Allium ampeloprasum ssp. ampeloprasum) is a type of leek (A. ampeloprasum). It is grown by several southwest Missouri producers and consumers using the same practices as those used for true garlic cultivars. Consumers also like elephant garlic because of its large cloves, which makes food preparation simpler. Elephant garlic has larger bulbs at maturity than true garlic; in fact, one clove can weigh as much as an entire bulb of true garlic (Boyhan et al., 2012).

Because plants are typically sterile, garlic is vegetatively propagated by dividing bulbs into individual cloves (Bandara et al., 2000; Meredith, 2014). The best planting densities in a study performed in Mexico were between two and four plants per square foot (Castellanos et al., 2004). Each clove should be planted with the basal plate down. Mechanical planting is sometimes used, but proper orientation of the cloves cannot be guaranteed. When planted upside down, growth tends to be uneven and slow; therefore, ultimately, yield and quality can be reduced (Castellanos et al., 2004). Because garlic is a high-value crop and uses large amounts of nutrients, growers should devote their best soils to growing it (Bachman and Hinman, 2008). Pennsylvania State University Extension specialists recommend applying the equivalent of $75 \mathrm{lb} /$ acre of nitrogen at planting, $25 \mathrm{lb}$ when the plants are 6 inches tall, and $25 \mathrm{lb}$ at $\approx 1$ May (Ford et al., 2014). The use of border rows is sometimes recommended because a significant "border effect" may exist at a field edge, thus causing plants to grow differently than other plants in the research project (Davis et al., 2017). Mulch is often recommended because garlic is a poor competitor with weeds. Garlic emerged sooner, started to grow faster, and had greater yields and bulb diameters when black plastic was used instead of bare soil/wheat (Triticum aestivum) straw mulch in Illinois (Walters, 2008). Instead of black plastic, other types of mulch such as straw can be used (Volk et al., 2004). Garlic harvest begins when the lower onethird of the leaves begin to brown and dry, and bulb size will double during the last stages of growth (Volk and Stern, 2009). Garlic bulb formation will stop when soil temperatures increase to more than $90{ }^{\circ} \mathrm{F}$ (Bachman and Hinman, 2008). The entire plant is pulled or dug from the ground. Bulbs are then typically air-dried before use (Bratsch et al., 2009).

Meredith (2014) stated that garlic is usually planted in the fall and harvested $\approx 9$ months later unless the winters are exceptionally severe. Fall plantings provide garlic an opportunity to establish a root system, but not so much time that growth aboveground is exposed to winter cold. Plants go dormant during the colder months of winter and resume growth in the spring (Volk et al., 2004). Spring regrowth begins in midMarch in the upper midwestern United States (Walters, 2008). In southwest Missouri, fall-planted garlic tends to sprout before the ground freezes and often overwinters with the foliage aboveground. The formation of bulbs and cloves depended on daylength and soil temperature according to a project performed in Canada (Bandara et al., 2000). According to Kamenetsky et al. (2004), short days are required for both dormancy induction of axillary buds and clove formation. Most published research reported higher yield and quality when garlic was planted in the fall, although results varied on whether garlic grew better when planted in early fall vs. later in the fall. The most beneficial time to plant garlic in Oregon is from September through November according to Bubl (2015). Garlic planted in earlyto mid-October in Virginia had higher yields than garlic planted later in the fall (Bratsch et al., 2009). In Egypt, one study indicated that a later fall planting resulted in higher yields (Foda, 1977), but another study concluded that yields were higher when garlic was planted early in the fall (ElZohiri and Farag, 2014). A second study performed in Egypt found that garlic cultivars with different bulb skin colors (red or white) varied in yield based on planting date, although the garlic on the final planting dates had the lowest yields (Youssef and Tony, 2014). The findings of Youssef and Tony (2014) agreed with the results of research conducted in Virginia that indicated that garlic planted earlier in the fall had higher yields than garlic planted later in the season (Bratsch et al., 2009). Similar trends were seen in Bangladesh (Islam et al., 1998; Rahim et al., 2003). A study performed in Brazil found that cultivars differed in production based on fall planting dates but, in general, a larger percentage of bulbs emerged when planted on the earlier dates (de Resende et al., 2011). Yields were also higher in Brazil when garlic was planted in late February rather than on the traditional planting dates in mid-March to mid-April (Pinto et al., 2000). February is a late summer month in Brazil, whereas March and April are early fall months.

A few studies have examined yields when garlic was planted in the spring. Fall planting resulted in better yields than spring planting in Saskatchewan, Canada (Waterer and Schmitz, 1993). Spring-planted garlic can develop successfully if it is planted in March or April in Virginia (Relf, 2015). Spring-planted bulbs that received preplant chilling of $\approx 39{ }^{\circ} \mathrm{F}$ for 45 to $60 \mathrm{~d}$ were larger and had more cloves than bulbs that received no chilling or a longer chilling period in Canada (Bandara et al., 2000). Large vegetative plants that developed under cool temperatures and a short daylength had the highest yields, and early planting resulted in larger yields in Bangladesh (Raham and Talukda, 1986).

Average yield per acre of garlic varies by location in the United States. Lee Farms LLC (Truxton, $\mathrm{MO}$ ) owner R. Lee (personal communication) reported he gets yields of 4000 to $5000 \mathrm{lb} /$ acre in Missouri. C.L. Stewart (personal communication) of Cornell University reported yields of 8000 to $10,000 \mathrm{lb} /$ acre in New York.

Despite studies involving planting dates for garlic in other areas, no such work has been reported for garlic in Missouri. Missouri growers traditionally plant garlic in the fall, from mid- to late-October. The project was initiated after a local grower claimed that garlic yields are larger if planted in early- to mid-September. The objectives of this study were to evaluate yields of two garlic cultivars and elephant garlic planted on four dates in the fall and in early spring at two locations in southwest Missouri in 2016-18.

\section{Materials and methods}

Garlic planting date studies were completed over two production cycles 
(2016-18) at two locations in southwest Missouri. The sites were the Missouri State University William H. Darr Agricultural Center (Darr Center) in Springfield, MO (lat. $37.172^{\circ} \mathrm{N}$, long. $93.317^{\circ} \mathrm{W}$, altitude $1243 \mathrm{ft}$ ), and Braker Farm near Oronogo, MO (lat. $37.363^{\circ} \mathrm{N}$, long. $94.466^{\circ} \mathrm{W}$, altitude $954 \mathrm{ft}$ ). The two sites are 65 miles apart. Annual precipitation averages 45.5 inches at Springfield and 46.6 inches at Oronogo. The soil at the Darr Center site is a combination of Wanda silt loam (fine-loamy, mixed, active, mesic typic Paleudolls) and Newtonia silt loam (fine-silty, mixed, superactive, thermic typic Paleudolls); both are upland, very deep, well-drained soils. Soil tests indicated a $\mathrm{pH}$ of 5.8 , organic matter of $3.6 \%$, cation exchange capacity of $14.6 \mathrm{meq} / 100 \mathrm{~g}$, and adequate levels of phosphorus $(\mathrm{P})$, potassium $(\mathrm{K})$, calcium $(\mathrm{Ca})$, and magnesium $(\mathrm{Mg})$ based on recommendations from the University of Missouri soil testing laboratory for garlic production. The soil at the Braker Farm is a Parsons silt loam (fine, mixed, active, thermic Mollic Albaqualfs) with deep, level to gently sloping, and somewhat poorly drained soil. Soil tests indicated a $\mathrm{pH}$ of 6.9 , organic matter of $2.5 \%$, cation exchange capacity of $7.2 \mathrm{meq} / 100 \mathrm{~g}$, low levels of $\mathrm{K}$, and adequate levels of $\mathrm{P}, \mathrm{Ca}$, and $\mathrm{Mg}$.

These studies evaluated two garlic cultivars, softneck Inchelium Red and hardneck German White, and a selection of elephant garlic. Planting stock was obtained for both production cycles from Keene Organics (Sun Prairie, WI). In 2016, elephant garlic was purchased from Territorial Seed Co. (Cottage Grove, OR). The elephant garlic from Territorial Seed was not shipped in time for the first fall planting in 2016 (22 Sept.). For each year of the study, raised beds 30 inches wide and 6 inches high were formed at both sites. Beds were covered with 1.25-mil black plastic mulch (FilmTech Corp., Allentown, PA). A Chapin drip irrigation line (Jain Irrigation, Jalgaon, India) with emitter spacing of 12 inches was laid beneath the plastic; however, drip irrigation was not required either year of the study. Beds were spaced $5 \mathrm{ft}$ apart on center. A preplant application equivalent to $75 \mathrm{lb} /$ acre nitrogen (Twin Pine 13N-5.7P-10.8K;
Knot Fertilizer Co., Knox, IN) was incorporated in the beds before planting the garlic. Five planting dates used in the study in 2016-17 were 22 Sept. (D1), 4 Oct. (D2), 21 Oct. (D3), 4 Nov. (D4), and 24 Feb. 2017 (D5). Planting dates in 2017-18 were 15 Sept. (D1), 6 Oct. (D2), 20 Oct. (D3), 3 Nov. (D4), and 27 Feb. 2018 (D5). Planting stock for the late winter planting dates was vernalized in a refrigerator for $84 \mathrm{~d}$ at $33{ }^{\circ} \mathrm{F}$ air temperature. At each location for both years, 50 cloves of each cultivar per planting date were randomly assigned to a plot in the planting area (Fig. 1) and spaced 4 inches apart. Plot sizes were $\approx 3 \times 4 \mathrm{ft}$ wide. Ten bulbs were randomly selected for data analysis for each cultivar per planting date per site. Border plots of elephant garlic were planted at the ends of each bed. Straw mulch was placed between beds to control weeds. In addition to the preplant nitrogen, which was broadcast by hand and then tilled under, a liquid formulation of 75 $\mathrm{lb} / \mathrm{acre}$ nitrogen (Nature's Source $10 \mathrm{~N}-1.7 \mathrm{P}-2.5 \mathrm{~K}$; Ball DPF, Sherman, TX) was hand-applied to the beds in early March. Plants were harvested when the lowest three leaves had dried. Bulbs were air-dried in a greenhouse in Springfield, MO, with average ambient temperatures of 85 to $90^{\circ} \mathrm{F}$. Data measured after a $6-$ week curing period included bulb weight, bulb diameter, number of cloves per bulb, and clove weight. Ten individual bulbs of each cultivar for each planting date were weighed and measured.

Statistical analyses were conducted based on a three-factor design including location, planting date, and garlic cultivar information. The threeway analysis was conducted using statistical software (IBM SPSS Statistics version 19.0 for Windows; IBM, Armonk, NY), the general linear model, and univariate procedure, with significance in interactions reported as $P \leq 0.05,0.01$, or 0.001 , or not significant. Due to many significant interactions, subsequent analyses of individual factors within subsets of the other two factors were conducted using SPSS Compare Means and one-way analysis of variance (ANOVA), with mean separation by Duncan's test with $P \leq 0.05$. The Duncan's test was used only when the ANOVA F-test significance was $<0.05$.

\section{Results 2016-17 at Braker Farm}

Elephant garlic. There were no differences in the average bulb diameter for any of the planting dates (Table 1). Elephant garlic clove weight was larger when fall-planted than when spring-planted. Clove numbers for the elephant garlic were slightly enhanced for D3 and D4 compared to the D2-planted garlic, but clove numbers for the spring garlic were not significantly different from those planted on any of the other dates.

'German White'. Bulb weights were highest for garlic planted on DI and D2 and lowest when planted on D5 (Table 1). Clove weight was highest for the garlic planted in Fall 2016 and lowest when planted in Spring 2017. The clove number was statistically lower for garlic planted in Spring

\begin{tabular}{|c|c|c|c|c|}
\hline 'Inchelium & 'German & Elephant & 'German & 'Inchelium \\
Red' & White' Date 4 & Date 3 & White' & Red' \\
Date 1 & 4 Nov. & 21 Oct. & Date 5 & Date 2 \\
22 Sept. & & & 24 Feb. 2017 & 4 Oct. \\
\hline 'German & Elephant & 'Inchelium & 'German & Elephant \\
White' & Date 2 & Red' & White' & Date 5 \\
Date 1 & 4 Oct. & Date 3 & Date 2 & 24 Feb. 2017 \\
22 Sept. & & 21 Oct. & 4 Oct. & \\
\hline Elephant & 'Inchelium & 'Inchelium & Elephant & 'German \\
Date 1 & Red' & Red' & Date 4 & White' Date 3 \\
22 Sept. & Date 4 & Date 5 & 4 Nov. & 21 Oct. \\
& 4 Nov. & 24 Feb. 2017 & & \\
\hline
\end{tabular}

Fig. 1. Example of the planting layout used to compare yields of 'Inchelium Red', 'German White', and elephant garlic planted on five different dates at two sites (Springfield and Oronogo, MO) in 2016-17. A similar planting layout was used in 2017-18. 
Table 1. Effects of planting date and location on garlic bulb weight, bulb diameter, clove weight, and clove number by garlic type in southwest Missouri. ${ }^{z}$

\begin{tabular}{|c|c|c|c|c|c|c|c|c|c|}
\hline \multirow[b]{2}{*}{ Garlic type or cultivar } & \multirow[b]{2}{*}{ Planting date } & \multicolumn{2}{|c|}{ Avg bulb wt $(g)^{z}$} & \multicolumn{2}{|c|}{$\begin{array}{l}\text { Avg bulb diam } \\
(\mathrm{cm})^{\mathrm{z}}\end{array}$} & \multicolumn{2}{|c|}{ Avg clove wt (g) } & \multicolumn{2}{|c|}{ Cloves (no.) } \\
\hline & & Braker & Darr & Braker & Darr & Braker & Darr & Braker & Darr \\
\hline \multirow[t]{4}{*}{ Elephant garlic } & 22 Sept. 2016 (Dl) & & & & & & & & \\
\hline & 4 Oct. 2016 (D2) & $213.3 \mathrm{a}^{\mathrm{y}}$ & $237.0 \mathrm{a}$ & $8.7 \mathrm{a}$ & $9.3 \mathrm{a}^{\mathrm{y}}$ & $20.4 \mathrm{a}$ & $22.7 \mathrm{a}$ & $5.2 \mathrm{~b}$ & $5.5 \mathrm{a}$ \\
\hline & 21 Oct. 2016 (D3) & $215.5 \mathrm{a}$ & $167.8 \mathrm{c}$ & $8.6 \mathrm{a}$ & $8.9 \mathrm{a}$ & $20.9 a$ & $15.8 \mathrm{c}$ & $5.9 \mathrm{a}$ & $5.1 \mathrm{a}$ \\
\hline & 4 Nov. 2016 (D4) & $226.5 \mathrm{a}$ & $195.9 \mathrm{~b}$ & $8.8 \mathrm{a}$ & $8.3 \mathrm{~b}$ & $21.3 \mathrm{a}$ & $18.2 \mathrm{~b}$ & $5.9 \mathrm{a}$ & $5.5 \mathrm{a}$ \\
\hline & 4 Oct. $2016(\mathrm{D} 2)$ & $109.7 \mathrm{a}$ & $125.8 \mathrm{a}$ & $6.6 \mathrm{ab}$ & $7.0 \mathrm{a}$ & $9.8 \mathrm{~b}$ & $8.7 \mathrm{a}$ & $9.8 \mathrm{a}$ & $11.2 \mathrm{a}$ \\
\hline & 21 Oct. 2016 (D3) & $99.2 \mathrm{~b}$ & $-^{\mathrm{x}}$ & $6.4 \mathrm{a}$ & - & $8.8 \mathrm{c}$ & $8.0 \mathrm{a}$ & $8.9 \mathrm{a}$ & - \\
\hline & 4 Nov. 2016 (D4) & $95.5 \mathrm{~b}$ & $93.8 \mathrm{c}$ & $6.7 \mathrm{a}$ & $6.6 \mathrm{a}$ & $8.6 \mathrm{c}$ & $10.2 \mathrm{a}$ & $9.5 \mathrm{a}$ & $11.2 \mathrm{a}$ \\
\hline & 27 Feb. 2017 (D5) & $60.6 \mathrm{c}$ & $63.2 \mathrm{~d}$ & $5.5 \mathrm{~b}$ & $5.5 \mathrm{~b}$ & $5.7 \mathrm{~d}$ & $9.2 \mathrm{a}$ & $7.5 \mathrm{~b}$ & $6.7 \mathrm{~b}$ \\
\hline \multirow[t]{2}{*}{ Inchelium Red } & 22 Sept. 2016 (D1) & - & $129.5 \mathrm{a}$ & - & $7.7 \mathrm{a}$ & - & $7.4 \mathrm{a}$ & - & $21.7 \mathrm{a}$ \\
\hline & 4 Oct. 2016 (D2) & $134.9 \mathrm{a}$ & $137.9 \mathrm{a}$ & $7.8 \mathrm{a}$ & $7.9 \mathrm{a}$ & $12.7 \mathrm{a}$ & $6.4 \mathrm{~b}$ & $17.5 \mathrm{a}$ & $19.6 \mathrm{~b}$ \\
\hline \multirow[t]{5}{*}{ Elephant garlic } & 15 Sept. 2017 (D1) & $107.1 \mathrm{~b}$ & $93.6 \mathrm{ab}$ & $8.3 \mathrm{a}$ & $7.8 \mathrm{a}$ & $10.1 \mathrm{a}$ & $8.7 \mathrm{a}$ & $5.5 \mathrm{a}$ & $5.8 \mathrm{ab}$ \\
\hline & 6 Oct. 2017 (D2) & $52.3 \mathrm{~d}$ & $91.6 \mathrm{ab}$ & $6.4 \mathrm{~b}$ & $7.5 \mathrm{a}$ & $5.5 \mathrm{~b}$ & $8.7 \mathrm{a}$ & $4.5 \mathrm{a}$ & $5.4 \mathrm{ab}$ \\
\hline & 20 Oct. 2017 (D3) & $102.5 \mathrm{~b}$ & 83.7 b & $7.9 \mathrm{a}$ & $7.5 \mathrm{a}$ & $9.3 \mathrm{a}$ & $8.0 \mathrm{a}$ & $5.6 \mathrm{a}$ & $6.1 \mathrm{a}$ \\
\hline & 3 Nov. 2017 (D4) & $135.2 \mathrm{a}$ & $116.1 \mathrm{a}$ & $8.4 \mathrm{a}$ & $8.1 \mathrm{a}$ & $11.1 \mathrm{a}$ & $10.2 \mathrm{a}$ & $5.0 \mathrm{a}$ & $4.7 \mathrm{bc}$ \\
\hline & 27 Feb. 2018 (D5) & $62.4 c$ & $97.7 \mathrm{ab}$ & $6.3 \mathrm{~b}$ & $7.7 \mathrm{a}$ & $4.9 \mathrm{~b}$ & $9.2 \mathrm{a}$ & $5.2 \mathrm{a}$ & $4.0 \mathrm{c}$ \\
\hline \multirow[t]{5}{*}{ German White } & 15 Sept. 2017 (DI) & $87.9 \mathrm{a}$ & $74.4 \mathrm{a}$ & $7.1 \mathrm{ab}$ & $7.0 \mathrm{a}$ & $7.2 \mathrm{ab}$ & $7.4 \mathrm{a}$ & $8.5 \mathrm{a}$ & $7.7 \mathrm{a}$ \\
\hline & 6 Oct. 2017 (D2) & $83.2 \mathrm{a}$ & $67.8 \mathrm{ab}$ & $7.4 \mathrm{a}$ & $6.6 \mathrm{a}$ & $7.8 \mathrm{a}$ & $6.4 \mathrm{ab}$ & $8.2 \mathrm{a}$ & $6.3 \mathrm{~b}$ \\
\hline & 20 Oct. 2017 (D3) & $73.0 \mathrm{~b}$ & $67.8 \mathrm{ab}$ & $7.0 \mathrm{~b}$ & $6.7 \mathrm{a}$ & $6.9 \mathrm{~b}$ & $6.4 \mathrm{ab}$ & $9.0 \mathrm{a}$ & $6.9 \mathrm{ab}$ \\
\hline & 3 Nov. 2017 (D4) & $81.2 \mathrm{a}$ & $53.1 \mathrm{c}$ & $7.3 \mathrm{ab}$ & $6.5 \mathrm{a}$ & $7.6 \mathrm{ab}$ & $5.0 \mathrm{c}$ & $9.0 \mathrm{a}$ & $4.1 \mathrm{c}$ \\
\hline & 27 Feb. 2018 (D5) & $55.3 \mathrm{c}$ & $65.3 \mathrm{~b}$ & $6.2 c$ & $6.6 \mathrm{a}$ & $5.4 \mathrm{c}$ & $5.9 \mathrm{~b}$ & $5.2 \mathrm{~b}$ & $6.2 \mathrm{~b}$ \\
\hline \multirow[t]{2}{*}{ Inchelium Red } & 15 Sept. 2017 (D1) & 95.8 a & $58.3 \mathrm{a}$ & $8.4 \mathrm{a}$ & $6.9 \mathrm{a}$ & $9.1 \mathrm{a}$ & $5.4 \mathrm{ab}$ & $12.1 \mathrm{a}$ & $10.8 \mathrm{c}$ \\
\hline & 6 Oct. 2017 (D2) & $96.0 \mathrm{a}$ & $61.5 \mathrm{a}$ & $7.8 \mathrm{~b}$ & $7.0 \mathrm{a}$ & $9.6 \mathrm{a}$ & $5.8 \mathrm{ab}$ & $11.4 \mathrm{a}$ & $13.5 \mathrm{ab}$ \\
\hline
\end{tabular}

${ }^{\mathrm{z}}$ This study was performed to assess the effects of five planting dates on the growth of three types of garlic at two farms in southwest Missouri. Braker Farm is near Oronogo, MO. Darr Farm is in Springfield, MO. $1 \mathrm{~g}=0.0353 \mathrm{oz}, \mathrm{l} \mathrm{cm}=0.3937$ inch.

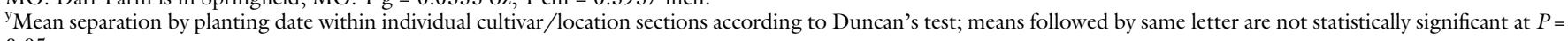
0.05 .

${ }^{\mathrm{x}}$ Insufficient data available for mean separation.

2017, with no significant differences among the clove numbers for garlic with fall planting dates.

'INCHELIUM RED'. The planting date only affected the bulb weight for the spring-planted garlic (Table 1). The average bulb diameter was largest for garlic planted on D2. Clove weight continued this trend, with the highest weight resulting from D2 plantings. Clove numbers were not significantly affected by the planting date. Data for 'Inchelium Red' were unavailable for $\mathrm{Dl}$.

\section{Darr Center}

Elephant Garlic. Elephant garlic bulb weight was highest for the D2 planting and lowest for the D3 and D5 planting (Table 1). The largest average bulb diameter occurred with the D2 and D3 plantings, and the smallest diameter occurred when garlic was planted in Spring 2017. Garlic planted in early-October had the highest clove weight, with D3 and D5 producing cloves that weighed $\approx 40 \%$ less. No significant difference in clove number was seen for the elephant garlic from any of the planting dates.

'German White'. Garlic planted on D2 had the highest bulb weight, and garlic with the lowest weights was planted on D5 (Table 1). The average bulb diameter was greater for fallplanted garlic, whereas garlic planted in Spring 2017 had the lowest bulb diameter. Clove weight tended to follow the same trend as bulb weight, with D2 plantings producing the greatest weights and D5 plantings producing the lowest bulb weights. Clove number was more than $60 \%$ greater for garlic planted in Fall 2016 compared with garlic planted in Spring 2017.

'INCHELIUM RED'. Garlic planted on D1 and D2 had significantly higher bulb weights than garlic planted on the other dates (Table 1). D1 and D2 plantings produced greater bulb diameters than later plantings. Clove weight was highest for garlic planted on Dl.

At both the Darr Center and Braker Farm, elephant garlic produced heavier and larger diameter bulbs and cloves and the lowest number of cloves at all planting dates (Table 1). This would be expected because the elephant garlic normally 
will have larger bulbs and cloves at maturity than true garlic (Fig. 2). 'German White' tended to produce the smallest bulbs and cloves, whereas the cultivar Inchelium Red consistently produced the greatest number of cloves per plant (Table 1 ).

The planting location (Darr vs. Braker) effect on garlic production varied among planting dates and type of garlic (Table 1). The production of smaller bulbs at later planting dates was a trend at both farms. These findings agree with the results of studies by Islam et al. (1998) and Rahim et al. (2003) performed in Bangladesh; they reported that plants attained higher vegetative growth with early plantings, which possibly led to larger bulbs. Research conducted in Virginia (Bratsch et al., 2009) indicated that garlic planted in early- to mid-October had higher yields than garlic planted later in the fall. Early- to mid-October plantings allowed for good root growth and some advanced top growth; earlier planting dates led to too much tender top growth by winter. Later planting dates may not have allowed time for adequate root development (Bratsch et al., 2009); this was also found in our study.

Higher yields at one site on one date but larger at the other location at another date may have occurred because the crops were exposed to differences in temperatures and moisture, as was determined by Volk and Stern (2009). Figure 3 shows the average monthly temperatures and precipitation at Joplin's regional airport (the closest weather station to Oronogo) and Springfield's national airport (closest weather station to the Springfield research location).

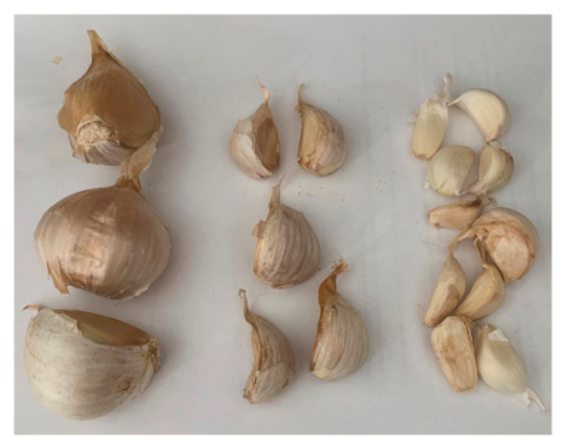

Fig. 2. Cloves of elephant garlic (left), 'German White' garlic (center), and 'Inchelium Red' garlic (right).
Although temperatures were often $\mathrm{l}$ to $2^{\circ} \mathrm{F}$ warmer in Joplin than in Springfield, overall temperatures were similar. In March, when active growth of garlic resumed, the Springfield location had 1 inch more rainfall than the Braker Farm. In April, Springfield had 12 inches of rain vs. 4.5 inches of rain in Joplin. Rainfall totals were above average at both locations in May.

\section{7-18 at Braker Farm}

Elephant garlic. The elephant garlic bulb weight was highest when planted at D4 and lowest (at only 38\% of the weight) when planted at D3 (Table 1). The elephant garlic bulb diameter and clove weight were higher when fall-planted, except for when planted on D2, which resulted in similar clove diameter and weight as the D5 planting.

'German White'. Bulb weight, bulb diameter, and clove weight at the Braker Farm were significantly lower for D5-planted bulbs (Table 1). Although fall-planted bulbs had higher yields, bulb weight of D3 plantings was the lowest of the fall plantings.

'INCHeLIUM RED'. As with the cultivar German White, yields were much lower for spring-planted bulbs, with spring-planted bulb weights and clove weights being $\approx 70 \%$ lower than the highest yielding fall-planted bulbs. Spring-planted bulb diameters were $35 \%$ lower than that of the highest yielding fall-planted bulbs (Table 1). However, D3 plantings had significantly reduced yields compared to the other fall plantings for clove weight.

When comparing garlic yields for a given planting date at Braker Farm (Table 1), elephant garlic had the highest bulb weights for all planting dates; these weights were $11 \%$ to $41 \%$ higher than those of the next highest yield, with the exception of early October, when it the lowest bulb weight was observed. 'Inchelium Red' had the lowest bulb weight for the spring planting.

\section{Darr Center}

Elephant. At the Darr Center, D3 bulb weight was the lowest (Table 1). In addition, there were no significant differences in the average bulb diameter or clove weight due to the planting date.
'German White'. Bulb weight, clove weight, and clove number were similar for D1, D2, and D3 (Table 1). The lowest yield of the same parameters occurred with D4 plantings. The spring planting yield did not significantly differ from either of the October plantings, with the yield tending to be slightly lower than the Dl yield. Bulb diameter was not significantly affected by the planting date at the Darr Center.

'INCHELIUM ReD'. Fall planting yields were not significantly different from one another (Table 1), but bulb weight and diameter were significantly lower for the Spring 2018 garlic plantings.

\section{Discussion and conclusions}

Clove numbers for 'Inchelium Red' were higher than those for 'German White' and elephant garlic at both planting locations and in both years of the study. This was expected because 'Inchelium Red' is a softneck garlic. Softneck types typically have more cloves per bulb because the plant puts more energy into producing a bulb that does not have a flower stalk (Frederick et al., 2014).

The data for 2016-17 plantings at both sites tended to suggest that garlic planted early had higher yields than garlic planted later in the fall. The results of the 2016-17 study were similar to those of many other studies (Lawande et al., 1993; Pinto et al., 2000; Rahim et al., 2003). Differences were seen in the yield of cultivars at each date, which was consistent with the findings by Youssef and Tony (2014), who performed a study in Egypt and found that white-skinned cultivars had greater yields when planted early but that red-skinned cultivars had higher yields when planted later in the season. Similarly, one garlic cultivar had the best yields from the first two planting dates in southern Brazil, but a second cultivar had a better yield with the second planting date and lowest yields with the third date (de Resende et al., 2011).

The planting location (Darr vs. Braker) effect on garlic production for the 2018 harvest varied among planting dates and garlic cultivars (Table 1). Elephant garlic tended to have higher bulb weights, bulb 


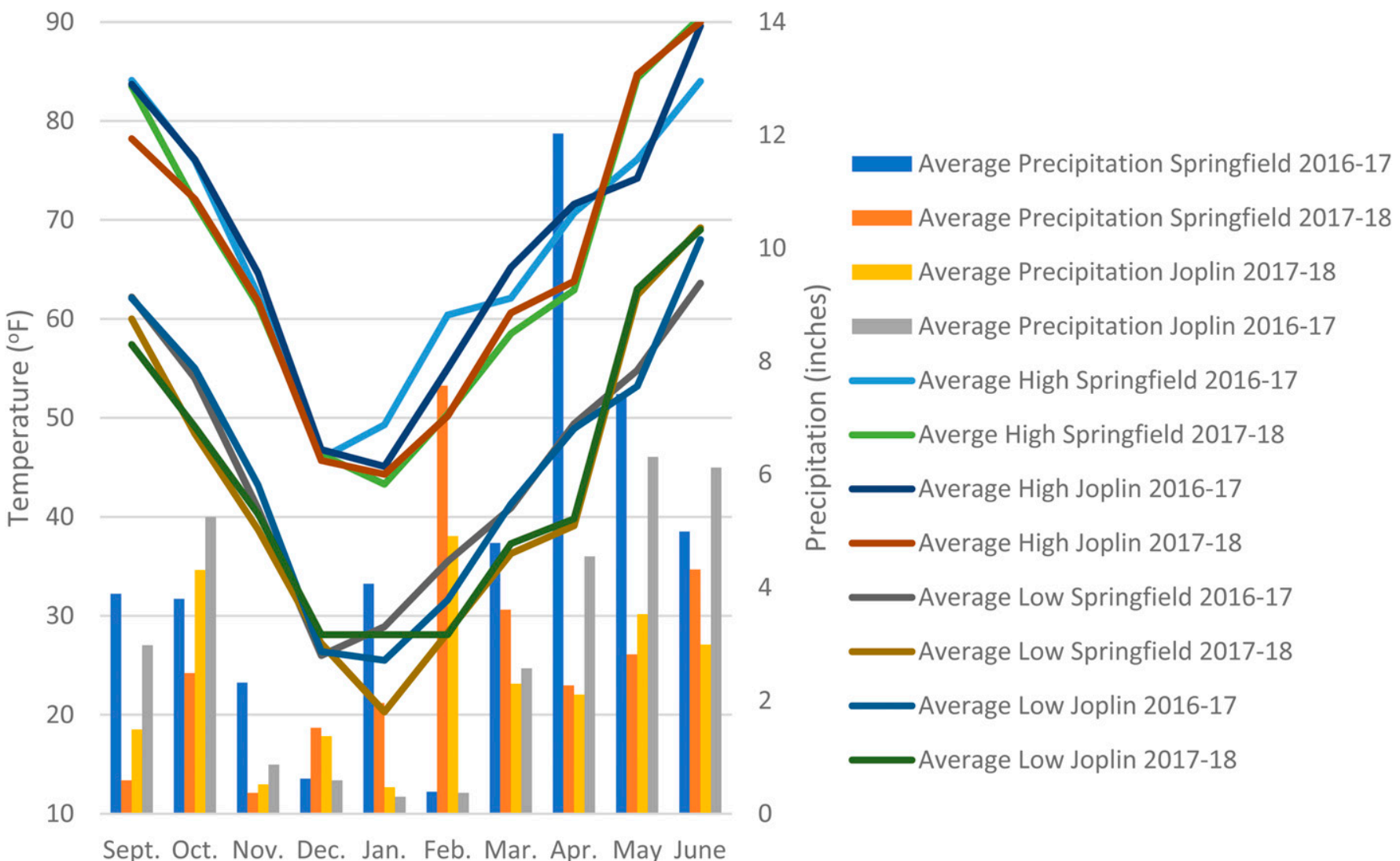

Fig. 3. Average monthly high and low temperatures (September to June) in Springfield and Joplin, MO (2016-18), as well as average precipitation for both cities during the 2 -year research project (U.S. Climate Data, 2019a, 2019b); $\left({ }^{\circ} \mathrm{F}-32\right) \div 1.8={ }^{\circ} \mathrm{C}$, 1 inch $=25.4 \mathrm{~mm}$.

diameters, and clove weights at Braker Farm, except for the D2 and D5 plantings. Elephant clove number was not significantly affected by location. The cultivars German White and Inchelium Red also tended to have higher yields at Braker Farm for all measured growth parameters for fall planting dates. Greater yields of 'German White' and 'Inchelium Red' tended to be obtained at the Darr Center from the Spring 2018 plantings compared with the Braker location. Although the plants at the Darr Center performed better than the plants at Braker Farm for the Spring 2018 date, the yields at both locations from spring planting tended to be lower than the yields of garlic planted on fall dates.

The inconsistencies between sites and among planting dates suggest that weather may have been a factor affecting garlic yields of the 2017-18 crops. Joplin recorded more rainfall in Fall 2017 than did Springfield (Fig. 3). Precipitation totals were well below average in November, December, and January at both sites, but rainfall in Springfield was higher than that in Joplin in February. The spring temperatures in Joplin were slightly higher than those in Springfield (Fig. 3). In addition, the average high and low temperatures in both Joplin and Springfield from September through December were higher than the 20-year average, although precipitation was considerably lower than the 20-year average. It is possible that the low precipitation at this time had a role in several local growers reporting that they lost their entire or almost entire garlic crops that were fall-planted. Temperatures from January through April were similar to the 20-year average, whereas average precipitation per month during this study varied in relation to the 20 -year averages. In Springfield, temperatures were consistently cool through early spring; however, in May, temperatures increased suddenly to nearly summer levels. Springfield precipitation in May was $\approx 50 \%$ lower than the 20 -year average.

The University of Georgia Cooperative Extension (Boyhan et al.,
2012 ) recommends that commercial growers should plant regular garlic 2 to 3 inches apart and elephant garlic 3 to 4 inches apart, with betweenrow spacing of 12 to 18 inches, depending on the width of the tractor tires. We did not need to use large equipment, so we planted our garlic 4 inches apart with 4 inches between rows. This made our plots much denser than is recommended for commercial growers. Perhaps because of our density, our yields in 2017 were $\approx 8500 \mathrm{lb} /$ acre, which is above average compared with the average yield reports from Lee Farms in Missouri and close to yields for commercial growers in New York. In 2018, however, our yield of $\approx 4000 \mathrm{lb} /$ acre was significantly lower than the New York growers' average yields and close to yields reported by Lee Farms.

Because results in 2017 and 2018 varied, further research is needed to determine the ideal planting date for garlic in southwest Missouri. We are continuing our research with the objective of defining the 
effect of location and weather on garlic yield and quality.

\section{Literature cited}

Bachman, J. and T. Hinman. 2008. Garlic: Organic production. 14 Dec. 2019. <https://www.attra.ncat.org/attra-pub/ summaries/summary.php?pub $=29>$.

Bandara, M., K. Tanino, A. Slinkard, and K. Krieger. 2000. Pre-plant chilling requirements for cloving of spring-planted garlic. Can. J. Plant Sci. 80:279-284.

Boriss, H. 2006. Commodity profile: Garlic. 9 Feb. 2020. <https://aic. ucdavis.edu/wp-content/uploads / 2019/01/agmr-profile-Garlic-2006B. pdf $>$.

Boyhan, G.E., W.T. Kelley, and D.M. Granberry. 2012. Production and management of garlic, elephant garlic and leek. Univ. Georgia Coop. Ext. Circ. 852. 9 Feb. 2020. <https://extension.uga.edu/ publications $/$ detail.html? number $=\mathrm{C} 852 \&$ title $=$ Production $\% 20$ and $\% 20$ Management $\% 20$ of $\% 20$ Garlic, $\% 20$ Elephant $\% 20$ Garlic\% 20 and\%20Leek>.

Bratsch, T., R. Morse, Z. Shen, and B. Benson. 2009. No-till organic culture of garlic utilizing different cover crop residues. 9 Feb. 2020. <https://www.pubs. ext.vt.edu/2906/2906-1389/29061389.html>.

Bubl, C. 2015. Get your garlic on: A primer on planting, growing and harvesting. 9 Feb. 2020. <https:// extension.oregonstate.edu/news/getyour-garlic-primer-planting-growingharvesting $>$.

Castellanos, J.Z., P. Vargas-Tapia, and J.L. Ojodeagua. 2004. Garlic productivity and profitability as affected by seed clove size, planting density and planting method. HortScience 39:1272-1277.

Cornell Cooperative Extension. 2019. Cornell vegetable program. 9 Feb. 2020. $<$ https://cvp.cce.cornell.edu/crop.php? $\mathrm{id}=14>$.

Davis, R.F., G.H. Harris, P.M. Roberts, and G.E. MacDonald. 2017. Designing research and demonstration tests for farmers' fields. Univ. Georgia Ext. Bul. 1177. 9 Feb. 2020. <https://secure.caes. uga.edu/extension/publications/files / pdf/B\%201177_4.PDF>.

de Resende, J.T.V., R.G.F. Morales, F.V. Resende, M.V. Faria, R. de Souza, and A. Marchese. 2011. Garlic vernalization and planting dates in Guarapuava. Hortic. Bras. 29:193-198.
Encyclopedia Britannica. 2016. Garlic. 9 Feb. 2020. <https://www.britannica. $\mathrm{com} /$ search?query $=$ garlic $>$.

Foda, S.A. 1977. Effect of date of planting on keeping quality of different garlic varieties. Agr. Res. Rev. 55:177-183.

Ford, T.G., S. Bogash, M. Orsolek, L. Kime, and J. Harper. 2014. Agricultural alternatives garlic production. $9 \mathrm{Feb}$. 2020. <https://www.extension.psu. edu/garlic-production $>$.

Frederick, P., B. Hlubik, and E. Leviant. 2014. Growing garlic in the home garden. 9 Feb. 2020. <https://njaes.rutgers. $\mathrm{edu} / \mathrm{fs} 1233>$.

Islam, M.N., M.A. Rahim, and H.R.M.M. Anawar. 1998. Effects of date of planting and different germplasms on the growth and seed bulb yield of garlic. Bangladesh J. Seed Sci. Technol. 2:45-54.

Kamenetsky, R., A. Barzilay, H. Rabinowitch, I. Shafir, and H. Zemah. 2004. Environmental control of garlic growth and florogenesis. J. Amer. Soc. Hort. Sci. 129: 144-151.

Lawande, K.L., R.D. Pawar, V.S. Supe, and P.N. Kale. 1993. Response of garlic to different dates of plantings. J. Maharashtra Agr. Univ. 18:314-315.

Lipka, M. 2011. Do you know where your garlic comes from? 9 Feb. 2020. <https:// www.bostonglobe.com/business/2011/ 12/18/you-know-where-your-garlic-comesfrom/KxPYsrCkZ5VdJK5LzROmCO/ story.html>.

Meredith, T.J. 2014. The complete book of garlic: A guide for gardeners, growers, and serious cooks. Timber Press, Portland, OR.

Naruka, I.S. and R.S. Dhaka. 2001. Effect of row spacing and nitrogen fertilizer on growth, yield, and composition of bulb in garlic (Allium sativum L.) cultivars. J. Spices Aromat. Crops 10:111-117.

Pinto, C.M.F., L.A. Maffia, V.W.D. Casali, R.D. Berger, and A.A. Cardoso. 2000. Production components and yield loss of garlic cultivars planted at different times in a field naturally infested with Sclerotium cepivorum. Intl. J. Pest Mgt. 46:67-72.

Raham, A.K.M. and M.R. Talukda. 1986. Influence of date of planting and plant spacing on growth and yield of garlic. Bangladesh J. Agr. 11:19-26.

Rahim, M.A., M.N.A. Chowdhury, H.R.M.M. Anwar, and M.S. Alam. 2003. Effect of planting dates on the growth and yield of garlic germplasm. Asian J. Plant Sci. Info. 22:171-174.

Relf, D. 2015. Onions, garlic and shallots. Virginia Coop. Ext. Pub. 426-411. 9 Feb. 2020. <https://www.pubs.ext.vt.edu/ content/dam/pubs_ext_vt_edu/426/ 426-411/426-411_pdf.pdf $>$.

Rosen, C.J. and C.B.S. Tong. 2001. Yield, dry matter partitioning, and storage quality of hardneck garlic as affected by soil amendments and scape removal. HortScience 36:1235-1239.

U.S. Climate Data. 2019a. Climate Joplin-Missouri. 9 Feb. 2020. <https:// www.usclimatedata.com/climate/joplin/ missouri/united-states/usmo0457/ $2016 / 1>$

U.S. Climate Data. 2019b. Climate Springfield-Missouri. 9 Feb. 2020. <https://www.usclimatedata.com/ climate/springfield/missouri/unitedstates/usmo0828/2016/l>.

U.S. Department of Agriculture. 2019. Taxon: Allium sativum L. 9 Feb. 2020. <https://npgsweb.ars-grin.gov/ gringlobal/taxonomydetail.aspx? id $=2368>$.

Volk, G.M. and D. Stern. 2009. Phenotypic characteristics of ten garlic cultivars grown at different North American locations. HortScience 44:1238-1247.

Volk, G.M., K.E. Rotindo, and W. Lyons. 2004. Low-temperature storage of garlic of spring planting. HortScience 39:571-573.

Walters, S.A. 2008. Production method and cultivar effects on garlic over-wintering survival, bulb quality and yield. HortTechnology 18:286-289.

Waterer, D. and D. Schmitz. 1993. Influence of variety and cultural practices on garlic yields in Saskatchewan. Can. J. Plant Sci. 74:611-614.

World Atlas. 2017. The top garlic producing countries in the world. 9 Feb. 2020. <https:// www.worldatlas.com/articles/the-top-garlicproducing-countries-in-the-world.html $>$.

Youssef, N.S. and H.S.H. Tony. 2014. Influence of planting date on the performance of new garlic genotype grown under El-Nina governorate conditions. Nat. Sci. 12:112-119.

El-Zohiri, S.S.M. and A.A. Farag. 2014. Relation planting date, cultivars and growing degree-days on growth yield and quality of garlic. Middle East J. Agr. Res. 3:1169-1183 